\title{
AUCTIONEERING IN THE PRACTICE OF ESTATE SURVEYORS AND VALUERS
}

\author{
C. O. Iroham
}

Department of Estate Management, Covenant University, Ota, Nigeria

H. I. Okagbue*

Department of Mathematics, Covenant University, Ota, Nigeria

M. E. Emetere

Department of Physics, Covenant University, Ota, Nigeria

T. O. Okonye

Department of Estate Management, Covenant University, Ota, Nigeria

\section{O. O. Temitope}

Tope and Tunde, Estate Surveyors and Valuers, Lagos, Nigeria

\section{N. J. Peter}

Department of Estate Management, Covenant University, Ota, Nigeria

\section{O. D. Durodola}

Department of Estate Management, Covenant University, Ota, Nigeria

${ }^{*}$ Corresponding Author

\begin{abstract}
There has been recent agitation amongst estate surveyors and valuers that auctioneering ought to be an aspect of their practice. This crave for supremacy appears contestable as they have not had an exclusive preserve in this aspect of practice coupled with the participation of other professionals. This study thereby aimed at discovering the prospect of estate surveyors and valuers in auctioneering amongst various stakeholders. Questionnaires were distributed to one hundred and eighty-three (183) estate surveyors and valuers in Lagos State, thirty-nine (39) auction houses in Lagos state and eleven (11) government agencies who require the services of auctioneers. The use of descriptive and inferential statistics such as the Relative Importance Index (RII), Chi-square test and Kruskal-Wallis test of significance were used in the analysis of the data. It was revealed that although the proportion of estate surveyors and valuers engaged in auctioneering are quite minimal, they are still substantial compared to other
\end{abstract}


C. O. Iroham, H. I. Okagbue, M. E. Emetere, T. O. Okonye, O. O. Temitope, N. J. Peter and O. D. Durodola

contending professionals. Estate surveyors and valuers are being vaunted to handle auctioneering even though caution has to be applied in the result not being significant at the 5\% significant level but significant at the $1 \%$ level of significance. The need for professionals exclusively known as auctioneers was advocated. The researchers thereby opine that the inclusion of auctioneering in the curriculum of all higher institutions offering estate management will be a welcome development that will give the estate surveyors and valuers the hedge for specialization as the professional auctioneer being advocated from responses in the study.

Key words: Auctioneering, professional auctioneers, Statistical tests, Estate Surveyors and Valuers, Nigeria.

Cite this Article: C. O. Iroham, H. I. Okagbue, M. E. Emetere, T. O. Okonye, O. O. Temitope, N. J. Peter and O. D. Durodola, Auctioneering in the Practice of Estate Surveyors and Valuers. International Journal of Advanced Research in Engineering and Technology, 10(2), 2019, pp. 624-635.

http://iaeme.com/Home/issue/IJARET?Volume $=10 \&$ Issue $=2$

\section{INTRODUCTION}

Auction which date back to antiquity, is derived from a latin word "augeo" which means "to increase" or "to augment". It is an approach used for buying and selling goods or services by way of bidding. Documentary evidence reveals that auctions could be traced back to $500 \mathrm{~B}$. C. in Greece where women were auctioned to potential suitors. The method of auction used was similar to the Dutch method in a descending method of auctioneering until a "befitting price" for the purchase of the woman is declared by the would-be suitor [1]. The Roman Empire also had proclivity for auctioneering, where "spoils of war" which included slaves were auctioned by Roman Soldiers known as "Magister Auctionarium". The process involved the soldiers driving a spear to the ground which heralded the commencement of the auctioneering exercise for potential buyers to begin their bids. Auctioneering was also used in the Roman Empire to liquidate debt from the assets of debtors impounded. In 193A.D. a remarkable experience in auctioneering took place when the entire Roman Empire was "put in the block" to Didius Julianus by the Praetorian Guard after the assassination of Emperor Pertinax. After the fall of the Roman Empire, auctioneering lost its popularity amongst the Europeans until the $18^{\text {th }}$ Century. In the $17^{\text {th }}$ and $18^{\text {th }}$ centuries some parts of England utilized "auction by candle" to conduct auction of goods and leaseholds. This auction came to an end at the expiration of the candle flame. This was intended to ensure that no bidder could predict the end of the auction and make a last second bid. Other unpredictable processes such as a footrace were also utilized in place of the expiration of a candle [2]. During the $16^{\text {th }}$ century, American auctioneering commenced when properties which include livestock, farms, crops, and lands were sold through auctions. However, during that period only officials who were Colonel had the license to coordinate auctions. This practice had been entrenched in the people that the official title of Colonel is still attributed to an auctioneer who could also be described as "knights of the hammer" [3]. Auctioneering has ever since been going on around the world but its actual date of commencement in Nigeria cannot be categorically ascertained even though it is believed to be traced to the era of the end of slave trade in the $\left(19^{\text {th }}\right.$ century). In those days, auctioneering had been handled by "quarks" which was characterized with gross illiteracy making people and the society at large look down on auctioneers. That perhaps explains why even though auctioneering has been practiced in Nigeria all these while, Estate Surveyors and Valuers have not necessarily been associated with the practice. Estate Surveyors and valuers have however been performing the traditional role of valuation, property management, property development, 
estate agency, feasibility/viability studies and more recently facility management. It has been revealed that there are even much more to undertake in the area of valuation particularly bill board valuation which has not been explored by the estate surveyors and valuers [4]. Hence, the surge in technological development, quest for human development, stiff competition in the business world, vagaries in government policies and legislation and prevailing economic recession have forced the extension of practice of Estate Surveyors and Valuers. These professionals have now enforced their roles in project management and finance, asset management, infrastructure management, real estate consultancy, training and market research, Arbitration, development finance, mortgage brokerage amongst others. However, in recent times, the Estate Surveyors and Valuers have begun to exert their role in auctioneering. This is corroborated with the establishment of fifteen (15) faculties (specialized areas) known as business divisions of which auctioneering forms part. These business divisions are established by the Nigerian Institution of Estate Surveyors and Valuers (NIESV), a body established to protect the interest of her members. The business divisions function amongst others is to train members in core competency of practice. The auctioneering business division is not left out in doing this even though there is no obvious auctioneering study in the curriculum of estate management in the higher institutions of learning. Hence, no estate surveyor and valuer would have undertaken any auctioneering course in the course of training of becoming an Estate Surveyor and Valuer [5]. However, the establishment of the Certified Institute of Auctioneers of Nigeria (CIAN) made up of varied professionals in the field of estate surveying and valuation, accountancy, law, banking, marketing, credit management amongst others brought about a formal training of certain professionals in these fields of auctioneering. CIAN as a body also has four distinct areas of specialties training of core competency also regarded as faculties. These faculties are art \& artifacts auctioneering faculty; real - estate auctioneering faculty; automobile \& industrial auctioneering faculty, and benefit and charity auctioneering faculty. Even though the principles of auctioneering amongst the various faculties remain the same, the argument for unique application of this knowledge in specific areas of specialization brought about the constituent of the four core faculties. Auctioneers trained by the Institute have propensity of being called upon by various agencies to handle auctioneering jobs. Such agencies include: Nigeria Maritime Industry; Nigeria Customs Services; Banks, Asset Management Corporation of Nigeria (AMCON) and other Financial Institutions; Courts and the Nigeria Judiciary System, Local Chambers of Commerce; Manufacturers Association of Nigeria (MAN); Nigeria Police, Federal Road Safety Corps, National Drug Law Enforcement Agency (NDLEA) and other military and paramilitary outfits in the country amongst others.

The various professionals under the auspices of (CIAN) have since been practicing auctioneering. The auctions no matter the form or approach could be classified into four basic types: English, first-price sealed bid, second-price sealed bid, and Dutch ([6]; [7] and, [8]). The English bid is however regarded as the most popular and familiar [9]. In an English auction, bidders tend to observe the bid of others and thereafter choose to either gradually increase their bid or not. English auction bid comes with various variants such as the open outcry auction, where bidders are expected to call out prices; the silent auction where the auctioneer is responsible for calling out prices and the Japanese auction which involves bidders holding down buttons to call their bids. In sealed-bid auctions bidders concurrently submit written bids. While the highest bidder is selected and pays the amount for first-price, the highest bidder though selected pays the second highest bid in second-price. The Dutch auction process sees the auctioneer begin with a high asking price but gradually decreases such until a bidder accepts a stipulated price. Apart from the English auction, it is noteworthy to state that the bidding process is characterized by the fact that competitors are oblivious of the intending bid of one another. It has been proven that all four auction types result to identical revenue for the 
auctioneer under the circumstances of independent private values. This is however not the situation when bidders' valuations are linked as outcomes tend to be less definite [9]. However, no matter the auction type used, the success would be a function of how to attract bidders and avoid collusion [9], regarded as the design of the auctioneering process, [8]. More so, no matter the type of auction adopted, it must always satisfy two conditions: They are used to dispose any item; auctions are anonymous as the outcome does not depend on the identity of the bidders.

In order to successfully carry out auctioneering, Estate Surveyors and Valuers who have recently been agitating that auctioneering should be their exclusive preserve, as against the lawyers and accountants amongst other professionals, should be able to handle the processes. This is noteworthy at a time when attrition is even being threatened in the profession [10]

It is arguable though that the role as an Auctioneer is similar to that of an Estate Surveyor and Valuer who is expected to be knowledgeable in the art and science of valuation, land law, project management, market research, accounting principles, risk management, law of contract and torts, arbitration amongst others. More so, auctioneers just as estate surveyors and valuers have been reputed to be persons of integrity, nobility and honesty considering the vast worth of assets they deal with. Evidently, auctioneers could have access to certain bids which they are not supposed to divulge [11]. These organized, reliable, discrete, intelligent and accountable for confidentiality lifestyle which should characterize the auctioneer is supposed to be possessed by the estate surveyors and valuers [12]. If a thin line exists between the operations of estate surveying and valuation and that of auctioneering certain questions begin to agitate the mind of the researcher: what spurred the involvement in recent times of estate surveyors and valuers in auctioneering? What proportion of estate surveyors and valuers are involved in auctioneering? Which professional is best placed in handling auctioneering? What is the prospect of estate surveyors and valuers in auctioneering? This present study is poised to give answers to these questions. It is however apt before then to take a look at some earlier researches in real estate auctioneering.

\subsection{Auctioneering in Real Estate}

Practically every kind of goods that qualify as asset can be auctioned. These include antiques, art, procurement contracts, simple consumer goods, chattels, real estate, rights and licenses. Hence, both corporeal and incorporeal properties generally can be auctioned. However, the significance of auctioneering in the marketing of various other assets have been employed quite longer that its role in marketing of real estate which became prominent just in "modern times". Notwithstanding, there has been growing importance attached to auction as a veritable alternative to private negotiation while marketing real estate [13]. This is against the initial stigma associated with auction due to its connotation with distress properties in form of foreclosure or mortgage sales [14]. Such distress sales, which usually move faster during auction, are usually instigated by the mortgagee but over the years there have been apparent increase in owners initiating auctions due to the diminution of the stigma associated with auctions [13]. The parity given to both processes of sales has resulted in earlier researchers trying to compare revenue from auction to private negotiation when it comes to the marketing of real estate ([15; [16]; [17]). In fact, in academic research auctions have principally been studied under two major reasons: assessment of revenues from auction types to private negotiation while the other is the determination of factors on which auction succeeds, a function of the probability of sale, [18]. In real estate literature, formation of prices and comparison is evident. The revenue derived from both sales processes are considered equal [19]. [16] in a study carried out in Los Angeles, examining the relationship between prices from auction and 
predicted sales prices reveal association between auction and price discount. However, there are instances when revenue gotten from auction sales outweighs private negotiation ([20]; [21]; [15]; [22]; [9]). In fact, price premium has earlier been discovered from auction properties sales in the US [20]. Another earlier study that identified price premium in auctions is that by [23]. [21] also identified price premium in auction in Australia; [15] in New Zealand; and in Ireland, [22]. One reason adduced to this is evident for instance if price paid by buyers can be connected with their private information, a way by which the seller takes advantage of the inherent "winner cause" situation. The earlier findings do not preclude the discovery of discounts in auction prices when compared to predicted market values though varying across various samples of the data [17]. In Nigeria, auction premium was also discovered from first-price sealed bid auction of Federal Government Landed Properties. This was attributed to the location of the property, bidders' turnout, number of bids received, bidders' characteristics and property types [18]. Hence, the returns on real estate auctions and private negotiation can be arguably competitive to each other depending on the scenario of the auctioneering process. In certain instances, real estate auctions have been shown to command higher prices when properties are in good locations and in a state of good decorative features compared to somewhat similar properties. However, during situations of troubled market when properties are distressed, private negotiation would invariably command higher prices [9].

As earlier mentioned, the other major research content in real estate auction literature is the determinants of auction successes. However, according to [13], less attention has been paid on this compared to the former. Nonetheless, Successes of real estate auction are hinged on vibrant market condition, higher potential number of bidders, better identity of the auction house, more distressed properties, more homogeneous properties, more centrally located properties amongst others. These are outcomes of studies in the US [14] and Singapore [13]. In the US, it was also discovered that auctions have better payoffs for sellers when large auctions can be held and economies of scale can be gotten from advertising and commission costs. ([24]; [16]).

Other researchers with the aid of models imbued location and property- specific variables [25]; instilled changes in market condition, [26] while [27] implanted differences in intermediaries. [15] infused not only locational and specific property characteristics but also impact of turnouts of bidders in auctions and the auctioneering house. Earlier literatures though theoretical have also attributed the import of turnout of bidders ([28]; [29]; and [30]). However, an empirical finding from [31] against envisaged expectations revealed that fewer bidders brought about average auctions prices. This result is contrary to findings of [32] and [33] that discovered a positive correlation between the number of bidders in auctions and the average size of bid for outer-continental offshore oil leases. [34] measuring the effect of competition on the share prices of companies that bid for land in Singapore reveals that the state of the economy, the time when auction is carried out, number of bidders and auctioneering houses and the increase acceptance of auction as a mode for sales affects the success of auction. With respect to online auctions certain factors were also discovered to affect the outcome of auctions. These factors include auction reservation price and its disclosure [35]. More participation of bidders and lesser experience of bidders also do give rise to enhance auction outcomes [36]. Using findings drawn from features of eBay website it was discovered that the number of unique bidders and the minimum bid that were tendered had positive effect on the auction price [37].

Most researchers no matter the goods or services being auctioned have generally talked about the outcomes of auctioneering without first situating professionals who should handle the task. This is essential considering the fact that no specific laws have spelt that out. In Nigeria for instance the extant law governing auctioneering practice is derived from "Sales of 
Goods Act 1983" particularly section 58 of the Act. However, a Bill has been before the National Assembly to promulgate the Auctioneers Registration Council of Nigeria. The law though tries to harmonize and regulate the practice of auctioneering in Nigeria, still puts no profession exclusively in charge. This study is geared towards finding out the stake of the estate surveyors and valuers in auctioneering being a prominent professional in this struggle for supremacy.

\section{MATERIAL AND METHODS}

The study is a survey that spanned about four months, between September 2018 and January 2019. It entailed the distribution of questionnaires and a structured interview administered to various respondents. The questionnaires issued were to the practicing estate surveying and valuation firms in Lagos metropolis. The choice of Lagos was due to its preponderance of the head office of estate surveying firms in the study area compared to other parts of the country. Out of the total number of Eight Hundred and Forty-Six (846) Estate Surveying and Valuation Firms in the Country, a total of about (41\%) three hundred and forty-eight (348) are situated in Lagos State [38]. Using the [39] formula for calculating optimum sample size resulted to a total of One Hundred and Eighty-Three (183) Estate Surveying Firms that were surveyed. One Estate Surveyor and Valuer was required to represent each firm. The other group of respondents issued questionnaires is members of the Certified Institute of Auctioneers, Nigeria. Even though there are about two hundred and sixty-eight (268) members of CIAN across the country, the study focused only on the auction houses. This is to ensure that only those in active practice of auctioneering were studied. Of a total of 69 auction houses, thirty-nine (39), forming majority of them of about $57 \%$ are situated in Lagos alone [40]. The entire 39 auction houses formed the sample size of this work which is in line with [41] who advocated the entire study of a small sample frame, respondents' $\leq 30$. The study however studied all respondents since the margin is not much. That also entailed the exclusive study of those in Lagos. The other respondents studied are those agencies who do require the services of auctioneers. They range from the maritime industry, financial institutions, judiciary system, chambers of commerce, manufacturing association, military and paramilitary outfits. They are eleven (11) of them. These respondents were issued a structured questionnaire in the form of interview. The use of both descriptive and inferential statistics such as the relative importance index (RII), Chisquare test and Kruskal Wallis test of significance was used in the analysis of the data.

\section{RESULTS AND DISCUSSION}

Of the one hundred and eighty three (183) questionnaires distributed to the practicing estate surveying and valuation firms in the study area, a response rate of $84.69 \%$ was achieved. This is as a result of 155 questionnaires duly completed and returned. Twenty-eight out of the thirtynine auction houses responded to the questionnaires distributed. This recorded a response rate of $(71.79 \%)$. For agencies that require the services of auctioneers a response rate of $(81.18 \%)$ was recorded as nine out of the eleven respondents were available to attend to the structured interview.

The first poser seeks to identify why estate surveyors and valuers decided to start getting engaged in auctioneering in recent times. The question was directed to the estate surveyors and valuers. From reasons gotten from a study, such as the surge in technological development; quest for human development; stiff competition in the business world; vagaries in government policies and legislation and prevailing economic recession [5] informed the variables being ranked. The ranking was done with the use of Relative Importance Index (RII). The question which was presented using a 5point Likert scale from strongly disagree to strongly agree 
resulted to quest for human development being the highest scaled with a ranking of 4.13. Stiff competition in the business world ranked next with 3.86 while prevailing economic recession ranked next with 3.07. Vagaries in government policies and surge in technological development were ranked lowest with 2.38 and 2.04 respectively. It can be deduced that the profession of estate surveying and valuation is poised to enhancing capacity building that explains why the ranking of this variable was highest. The stiff competition is another variable that has resulted in the estate surveyor and valuer's involvement in auctioneering. This competition has also been seen in other areas of practice such as agency [42]. The country not too long survived recession in the economy that could explain why the estate surveyors and valuers had to consider auctioneering as an aspect of practice to salvage their professional relevance if a lull was experienced in other areas of practice. Since there are no government policies that might have affected the profession directly of recent and auctioneering can still be done without recourse to any technological aid that could explain the lowest ranking of these variables.

The research also found out the proportion of estate surveyors and valuers engaged in auctioneering. This question was directed to both the estate surveyors and valuers and the practicing auctioneers. Out of the one hundred and fifty five (155) respondents from estate surveyors and valuers 19 (nineteen) attested to the fact that they have handled auctioneering before or are actively involved in auctioneering. This is a dismal figure of just $(12.26 \%)$ of the professionals. However, eight (8) out of the 28 (28.57\%) of the auction houses studied are owned by estate surveyors and valuers with eight (8) others being real estate agents. This figure also represents $(28.57 \%)$ of the respondents. The other twelve (12) auction houses are owned by marketers $(3 ; 10.71 \%)$; social worker $(1 ; 3.57 \%)$; lawyers $(2 ; 7.14 \%)$; accountant $(4$, $14.29 \%)$; economist $(2,7.14 \%)$. It is observed that even though the proportion of estate surveyors and valuers who practice auctioneering is small the proportion of the established auction houses set up by estate surveyors and valuers and estate agents who are engaged in one aspect of real estate services known as estate agency are quite substantial compared to other professionals. The estate surveyors and valuers however do attest that they would love to practice auctioneering if the need arises. This was as a result of the response of $106(78.06 \%)$ estate surveyors and valuers who responded in the affirmative of longing to practice auctioneering amongst those yet to practice auctioneering.

Analyzing further to see if there are differences derived from the response of both groups, the chi-square test of significance was adopted at 5\% level of significance. It is obvious that the response from both groups appear quite small having $12.26 \%$ in the first group and $28.57 \%$ in the second group. However, comparing the response of the second group with other professionals, it could be arguable that the response is substantial. With the use of Chi-Square the result will first be shown in Table 1.

Table 1: Chi-square data on estate surveyors and valuers in auctioneering

\begin{tabular}{|c|c|c|c|}
\hline & Yes & No & Row Sub Total \\
\hline $\begin{array}{c}\text { Estate Surveyors and } \\
\text { Valuers in auctioneering } \\
\text { Practice }\end{array}$ & (A) $19(22.87)$ & (B) $136(132.13)$ & 155 \\
\hline $\begin{array}{c}\text { Auction Houses owned by } \\
\text { Estate Surveyors and } \\
\text { Valuers }\end{array}$ & (C) $8(4.13)$ & (D) $20(23.87)$ & 28 \\
\hline Column Sub Total & 27 & 156 & 183 Grand Total \\
\hline
\end{tabular}

Going by the chi-square formula of $\sum(\mathrm{O}-\mathrm{E})^{2}$ 
C. O. Iroham, H. I. Okagbue, M. E. Emetere, T. O. Okonye, O. O. Temitope, N. J. Peter and O. D. Durodola

$\mathrm{O}=$ Observed Event

$\mathrm{E}=$ Expected Event

The expected event is gotten from the product of subtotal of column and subtotal of row divided by the grand total for each cell. Based on the foregoing the chi-square for each cell from Cell A to Cell D is as follows:

Cell $\mathrm{A}=(19-22.87)^{2} / 22.87=0.6549 ;$ Cell $\mathrm{B}=(136-132.13)^{2} / 132.13=0.1133$;

Cell C $=(8-4.13)^{2} / 4.13=3.6264 ;$ Cell D $=(20-23.87)^{2} / 23.87=0.6274$

Going by the above formula a calculated chi-square of 5.022 is derived as against the chisquare value in the range of 3.841. This invariably results in rejecting any premise of no significant difference in both results. Hence, there should be caution in deducing the result. Hence, although the estate surveyors and valuers engaged in auctioneering are few, estate surveyors and valuers who engage in auctioneering could be quite substantial relative to other professionals.

This is buttressed from responses from the next question of which professional is best placed in handling auctioneering. For majority of the estate surveyors and valuers who have not engaged in auctioneering before, they would like to engage in such activity if the opportunity is given. Amongst the one hundred and fifty five (155) estate surveyors and valuers surveyed one hundred and fifteen $(115,74.19 \%)$ attested to the fact that estate surveyors and valuers are best apt in handling auctioneering. This, amongst various reasons is due to their knowledge in valuation, economics and law. The remaining forty $(40,25.81 \%)$ estate surveyors and valuers advocated that auctioneering should be a discipline on its own which should be regulated by a statutory body of auctioneers. The same question was asked the practicing auctioneers from the various auction houses. It was revealed that out of the twenty-eight (28) members surveyed, seventeen $(17,60.71 \%)$ alluded to the fact that estate surveyors and valuers are better placed in handling auctioneering. Of this seventeen members, eight (8) are estate surveyors and valuers, eight (8) are estate agents while one (1) is an economist. Reasons given are also in consonance with the first set of respondents which is based on their knowledge of valuation, economics and law. This buttress the confidence real estate practitioners have in their engagement in auctioneering. Out of the eleven members remaining, four $(5,17.86 \%)$ advocated that auctioneering should be a discipline of its own as the nucleus and intricacies of the discipline will best be handled. Of these four (5) respondents are the only social worker, the remaining economist and one (1) lawyer, accountant and marketer each. Inference can be drawn that these professional could perhaps have seen certain deficiencies in their profession with regards to auctioneering. From the remaining six (6) respondents in this group two (2, $7.14 \%)$ marketers; one $(1,3.57 \%)$ lawyer and three $(3,10.71 \%)$ accountants answered in favour of their profession as best in handling auctioneering. Reasons given are the conviction to persuade bidders, knowledge of legal intricacies and better placement of worth of assets as adduce by the marketers, lawyer and accountants respectively. In order to indorse this response the third respondents who are agencies that require the services of auctioneers were also asked the best professional in handling auctioneering. Although all the agencies agreed to the fact that they have in time past given the auctioneering job to any professional and even handled some jobs within the agency, their responses are as follows: Out of the nine respondents surveyed, four $(4,44.44 \%)$ were comfortable with estate surveyors and valuers, two (2, $22.22 \%$ ) advocated that auctioneering should be a profession on its own, one $(1,11.11 \%)$ suggested that a lawyer should be the professional for the auctioneering task while the remaining two $(2,22.22 \%)$ suggested that any one at all could handle auctioneering.

The respondents were then asked to scale their preference for the estate surveyor and valuer handling auctioneering. The scale of preference which puts a 1 point weight of strongly 
disagree through a 5 point weight of strongly agree on the likert scale appears that estate surveyors and valuers are better recognized amongst other professionals in handling auctioneering. However in order to confirm the fact that any difference in the responses could be attributed to chance a kruskal-wallis test of significance @ 5\% and 1\% was adopted.

Table 2: Kruskal Wallis data on estate surveyors and valuers as best professionals for auctioneering

\begin{tabular}{|c|c|c|}
\hline $\begin{array}{c}\text { Estate Surveyors and Valuers in } \\
\text { Practice }\end{array}$ & Auctioneers in practice & $\begin{array}{c}\text { Clients who require services of } \\
\text { auctioneers }\end{array}$ \\
\hline Mean Rank $=100.84$ & 82.2864 & 63.7922 \\
\hline Standard Deviation $(\mathrm{SD})=20.41$ & 53.24 & 51.69 \\
\hline Sum of Ranks $\mathrm{T}_{\mathrm{C}}=15629.84$ & 2304.02 & 574.13 \\
\hline
\end{tabular}

Going by the formula:

$$
\mathrm{H}=\underset{\mathrm{N}(\mathrm{N}+1) \mathrm{n}_{\mathrm{C}}}{\left[12 \times \sum \mathrm{T}_{\mathrm{C}}^{2}\right]-3 \times(\mathrm{N}+1)}
$$

$\mathrm{N}=$ the total number of participants in all groups combined.

$\mathrm{Tc}=$ the total rank for each group. $\mathrm{Tc} 1=76.5, \mathrm{Tc} 2=79.5$, and $\mathrm{Tc} 3=144$.

$\mathrm{n}_{\mathrm{c}}=$ the total number of participants in each group.

$$
\begin{aligned}
& \mathrm{H}=\left[\underline{12} \times \sum \mathrm{T}_{\mathrm{C}^{2}}^{2}\right]-3 \times(\mathrm{N}+1) \\
& \mathrm{N}(\mathrm{N}+1) \mathrm{n}_{\mathrm{C}} \\
& =\left[\underline{12} \times \sum \underline{\mathrm{T}}_{\mathrm{C}}{ }^{2}\right]-3 \times(\mathrm{N}+1) \\
& \text { 192(193) } \mathrm{n}_{\mathrm{C}} \\
& (12 / 37056 \times 1802291.37)-3 \times 192 \\
& (12 / 37056 \times 1802291.37)-576 \\
& 583.64-576=7.644
\end{aligned}
$$

Degrees of freedom of 2 (3 groups minus 1) gives a tabulated value of 5.991 and 9.21 at the $5 \%$ and $1 \%$ level of significance respectively. With the result from the kruskal-wallis test it is obvious that significant difference exists in the response (7.644 as against 5.991 at the 5\% level of significance); while no significance difference can be said to exist (7.644 as against 9.21 at the $1 \%$ level of significance). Thus, even though the estate surveyors and valuers appears to be advocated as a good professional to handle auctioneering that verdict cannot be conclusive as another strong point discovered is the constituent of professionals who will be known to engage solely in auctioneering.

Finally there was need to discover the prospect of auctioneering for the estate surveyors and valuers peradventure auctioneering becomes their exclusive preserve. A question was asked the various agencies that require services of an auctioneer how often auctioneering jobs are done by their agencies. It was revealed that at regular intervals auctioneering jobs are being handled. This ranged from once to thrice a month of assets of various types amounting to substantial value of minimum of Eight Hundred Thousand Naira (N800, 000) even though such values are arbitrarily decided particularly when handled internally. This finding is gotten from their head offices, annex or liaison offices in the study area. Information gathered revealed that across the nation these jobs are being given. However, there are no exclusive professionals the jobs are being given to. As earlier disclosed it was revealed that even internally within the agencies, auctioneering is been handled this is according to the respondents as a result of the fact that auctioneering as a profession is yet to be so pronounced in the society. 
C. O. Iroham, H. I. Okagbue, M. E. Emetere, T. O. Okonye, O. O. Temitope, N. J. Peter and O. D. Durodola

\section{CONCLUSION}

It is obvious that though the struggle for supremacy in the field of auctioneering is very pronounced amongst Estate Surveyors and Valuers, there are contending professionals who might not easily give in to their struggle. It is hereby imperative for the estate surveyors and valuers who have been attributed as a good professional in this field of auctioneering to get themselves ready for the task ahead starting with the inclusion of auctioneering in the curriculum of all higher institutions were estate surveyors and valuers in the offing are being prepared. Perhaps that might give the estate surveyor and valuer the needed standpoint of specialization as the professional auctioneer being advocated.

\section{ACKNOWLEDGEMENTS}

The authors acknowledge the sponsorship from Covenant University.

\section{REFERENCES}

[1] Odegaard, F. \& Anderson, C. K. (2014). All-pay auctions with pre- and post-bidding options. European Journal of Operational Research, 239(2), 579-592.

[2] Patten, R. W. (1970). Tatworth Candle Auction, Taylor \& Francis, Folklore 81(2), 132135.

[3] Ralph, C. (1964). Auctions and Auctioneering, California: University of California.

[4] Oni, A. S., Oloyede, S. A., Durodola, D. O., Ayedun, C. A. \& Akinjare, O. A. (2019). Estate surveyors and valuers involvement in outdoor advertising billboards valuation in Lagos, Nigeria. International Journal of Civil Engineering and Technology, 10(1), 167-176.

[5] Temitope, O.O. (2018). Auctioneering as an integral part of estate management practice in Nigeria. Paper presented at the Department of Estate management, Covenant University, Ota Town and Gown Seminar Series, September, 2018 (Unpublished).

[6] Milgrom, P.R. (1989). Auctions and Bidding: A Premier, Journal of Economic Perspectives, 3(3), 3-22.

[7] Baye, M.R. (2003). Managerial Economics and Business Strategy, International Edition: New York: McGraw - Hill.

[8] Klemperer, P. (2003). How (not) to Run Auctions: The European SG Auctions, Draft.

[9] Azasu, S. (2006). Auctions in the Real Estate Market - A Review, Working Paper No. 55, Building and Real Estate Economics, KTH, Stockholm.

[10] Peter, N. J., Ayedun, C. A. \& Iroham, C. O. (2018). Registration into associate membership status of the Nigerian Institution of Estate Surveyors and Valuers (NIESV): The challenges. International Journal of Civil Engineering and Technology, 9(10), 1239-1251.

[11] Bogetoft, P., Damgard, I., Jakobsen, T., Nielsen, K., Pagter, J. and Toft, T. (2006). A practical implementation of secure auctions based on multiparty integer computation. Proceedings of the 10th international conference on Financial Cryptography and Data Security, 142-147.

[12] Brown, J \& Pawlowski, M. (2016). How many contracts in an auction sale. Nottingham Law Journal, 25, 1-15.

[13] Ong, S. E., Lusht, K. \& Mak, C. Y. (2005). Factors influencing auction outcomes: bidder turnout,auction houses and market conditions. Journal of Real Estate Research, 27(2), 177191.

[14] Asabere, P., K., and Huffman, F. E. (1992). Price Determinants and Foreclosed Urban Land, Urban Studies, 29(5), 701-707. 
[15] Dotzour, M. G., Moorhead, E. and Winkler, D. T. (1998). Auctions on Residential Sales Prices in New Zealand. Journal of Real Estate Research, 16(1), 57-70.

[16] Mayer, C. J. (1998). Assessing the performance of real estate auctions. Real Estate Economics, 26(1), 41-66.

[17] Allen, M. T. and Swisher, J. (2000). An Analysis of the Price Formation Process at a HUD Auction. Journal of Real Estate Research, 20(3), 279-98.

[18] Amidu, A. and Agboola, A. O. (2009). Empirical evidence of the influences on first-price bid auction premiums, International Real Estate Review, 12(2), 157-170.

[19] Allen, M.T. (2001). Discounts in Real Estate Auction Prices: Evidence from South Florida. The Appraisal Journal, January 38-43.

[20] Lusht, K. M. (1990). Auctions Versus Private Sales of Houses: A Description and Empirical Analysis of Melbourne, Australia Market, Working Paper, The Pennsylvania State University, Philadelphia, PA.

[21] Lusht, K. M. (1996). Comparison of Prices Bought by English Auctions and Private Negotiations. Real Estate Economics, 24(4), 517-30.

[22] Stevenson, S. and Young, J. (2004). Valuation Accuracy: A Comparison of Residential Guide Prices and Auction Results, Property Management, 22(1), 45-54.

[23] AshenFelter, O. and Genesove, D. (1992). Testing for Price Anomalies in Real Estate Auctions, American Economic Review, 82, 501-505.

[24] Mayer, C. J. (1995). A Model of Negotiated Sales applied to Real-Estate Auctions, Journal of Urban Economics, 38(1), 1-22.

[25] DeBoer, L., Conrad, J. and McNamara, K. (1992). Property Tax Auction Sales, Land Economics, 68(1), 72-82.

[26] Anglin, P. (2003). The Value and Liquidity Effects of a Change in Market Conditions, AREUEA conference, Washington, DC, 2003 international conference on Financial Cryptography and Data Security, 142-147.

[27] Maher, C. (1989). Information Intermediaries and Sales Strategy in an Urban Housing Market: The Implications of Real Estate Auction in Melbourne, Urban Studies, 26(5), 495509.

[28] Vickrey, W. (1961). Counter speculation, Auctions and Competitive Seal Tenders, Journal of Finance, 16(1), 8-37.

[29] Milgrom, P. R. (1979). A Convergence Theorem for Competitive Bidding with Differential Information, Econometrica, 47(3), 679-88.

[30] McAfee, P. and McMillan, J. (1987). Auctions with a Stochastic Number of Bidders, Journal of Economic Theory, 43(1), 1-19.

[31] Burns, P. (1985). Market Structure and Buyer Behaviour: Price Adjustment in a Multiobject Progressive Oral Auction, Journal of Economic Behavior and Organization, 6(3) 275-300.

[32] Saidi, R. and Marsden, J. (1992). Number of Bids, Number of Bidders and Bidding Behavior in Outer-Continental Shelf Oil Lease Auction Markets, European Journal of Operational Research, 58(3), 335-343.

[33] Brown, L. McGreal, S. and Adair, A. (2013). The role of bidding in determining sales price for residential property. Journal of Housing Research, 22(1), 39-57.

[34] Ching, S. and Fu, Y. (2003). Contestability of Urban Land Market: An Event Study of Government Land Auctions in Hong Kong, Regional Science and Urban Economics, 33(6), 695-720.

[35] Walley, M.J.C. \& Fortin, D.R (2004). Behavioral outcomes from online auctions: reserve price, reserve disclosure, and initial bidding influences in the decision process. Journal of Business Research, 58(10), 1409-1418. 
C. O. Iroham, H. I. Okagbue, M. E. Emetere, T. O. Okonye, O. O. Temitope, N. J. Peter and O. D. Durodola

[36] Smith, C. W. (1989). Auction: the social construction of values. US: University of California Press

[37] Wan, W. and Teo, H. (2001). An Examination of Auction Price Determinants on Ebay. The 9th European Conference on Information Systems, July 27-29

[38] NIESV (2017). The Nigerian Institution of Estate Surveyors and Valuers Directory of Registered Members and Firms

[39] Kothari, C. R. (2004). Research Methodology: Methods and Techniques. (Second Revised Edition). New Delhi: New Age International Limited Publishers

[40] CIAN (2019). Directory of Certified Institute of Auctioneers Nigeria, available on line https://certifiedinstituteofauctioneers.org/membership directory.html retrieved on September 11, 2018

[41] Denscombe, M. (2003). The good research guide for small scale social research projects (Second Edition). Maidenhead Philadelphia: Open University Press

[42] Iroham, C. O., Oloyede, S. A., Ajibola, M. O. and Durodola, O. D. (2015). Towards an Effective Real Estate Agency Education: A stride to Efficiency in Nigeria. Procedia-Social and Behavioural Sciences 191, 2687-2692

[43] F. O. Jegede, E. O. Ibem and A A. Oluwatayo (2018), Manifestation of Defensible Space in Lagos State Development and Property Cooperation Housing Estates, Lagos, Nigeria, International Journal of Civil Engineering and Technology, 9(12), 2018, pp. 491-505

[44] Dr. Ozigbo Ikechukwu W and Ozigbo Chinelo Adline (2014), Real Estate Investment and Management Strategies in Nigeria: The Global Meltdown Challenge, International Journal of Management (IJM), Volume 5, Issue 10, October (2014), pp. 33-39. 